\title{
PENGARUH KEBIJAKAN KREDIT TERHADAP KINERJA KEUANGAN KOPERASI KARYAWAN CLARO HOTEL MAKASSAR (PERIODE TAHUN 2014-2018)
}

\author{
Nasrullah \\ Program Studi Manajemen Fakultas Ekonomi dan Bisnis \\ Universitas Muhammadiyah Makassar \\ Email: (nasrullah@unismuh.ac.id) \\ Kahar \\ Program Studi Manajemen Fakultas Ekonomi dan Bisnis \\ Universitas Muhammadiyah Makassar \\ Email: (kahargalesong91@gmail.com) \\ Nurul Azizah \\ Program Studi Manajemen Fakultas Ekonomi dan Bisnis \\ Universitas Muhammadiyah Makassar \\ Email: (nurulazizah@gmail.com)
}

\begin{abstract}
Credit Policy Analysis in a Cooperative is important, because the sustainability of a Cooperative depends on the performance of the Management in managing its Cooperative. To find out the performance of the Management, it is necessary to conduct a cooperative financial analysis through ratio analysis. The ratio analysis is in the form of accounts receivable turnover, liquidity ratios, and profitability ratios, looking at the financial report data of the Claro Hotel Makassar Employee Cooperative during the last 5 years period, from 2014 to 2018. The analytical method used is simple linear analysis, coefficient of determination R2 and test $t$ (partial) with the help of SPSS version 17.0. The results showed that the credit policy had a significant positive effect on the financial performance of Makassar hotel claro employee cooperatives (2014-2018 period).
\end{abstract}

Keywords: Credit Policy, Financial Performance.

\begin{abstract}
Abstrak
Analisis Kebijakan Kredit pada suatu Koperasi yang penting, karena keberlangsungan suatu Koperasi tergantung pada kinerja Pengurus dalam mengelola Koperasinya. Untuk mengetahui kinerja Pengurus tersebut perlu melakukan analisis keuangan Koperasi melalui analisis rasio. Analisis rasio tersebut berupa perputaran piutang, rasio likuiditas, dan rasio profitabilitas, melihat dari data laporan keuangan Koperasi Karyawan Claro Hotel Makassar selama periode 5 tahun terakhir yaitu tahun 2014 sampai tahun 2018. Metode analisis yang digunakan adalah analisis linear sederhana, koefisien determinasi $\mathrm{R}^{2}$ dan uji $\mathrm{t}$ (parsial) dengan bantuan SPSS versi 17.0. hasil penelitian menunjukkan bahwa kebijakan kredit berpengaruh positif tidak signifikan terhadap kinerja keuangan koperasi karyawan claro hotel makassar (periode tahun 2014-2018).
\end{abstract}

Kata Kunci: Kebijakan Kredit, Kinerja Keuangan. 


\section{PENDAHULUAN}

Seiring dengan perkembangan jaman, koperasi telah ikut berperan aktif dan terlibat lebih luas dalam berbagai kegiatan ekonomi. Oleh karena itu, maka dapat dikatakan bahwa koperasi memiliki peran penting dalam tata perekonomian Indonesia. Sehingga jelaslah bahwa koperasi memang salah satu pelaku ekonomi yang dapat membantu indonesia dalam mewujudkan masyarakat adil dan makmur.

Dalam peraturan Menteri Negara Koperasi, dan Usaha Kecil dan Menengah Republik Indonesia No. 21/Per/M.KUKM/XI/2008 mendefinisi kan bahwa koperasi adalah badan usaha yang beranggotakan orang-seorang atau badan hukum koperasi dengan melandaskan kegiatannya berdasarkan prinsip koperasi sekaligus sebagai gerakan ekonomi rakyat yang berdasar atas asas kekeluargaan sebagaimana yang dimaksud dalam peraturan perundang-undangan perkoperasian. Sehingga tujuan dari koperasi itu sendiri ialah untuk meningkatkan taraf hidup dan kesejahteraan anggota-anggotanya dan memenuhi kebutuhan anggotanya.

Sebagai badan usaha yang mempunyai banyak anggota dan pelanggan, menjadikan koperasi banyak memberikan kebijakan kredit yang sangat mempengaruhi kesehatan kinerja keuangan koperasi itu sendiri, dan kesejahteraan para anggota koperasi, maka dari itu dalam menjalankan kebijakan kredit koperasi ada beberapa hal yang perlu diperhatikan yaitu dimana dalam memberi kebijakan pinjaman atau kredit koperasi harus memperhatikan faktor-faktor yang meyakinkan dalam pemberian kredit untuk memastikan kelancaran pembayaran kredit. Hal ini dilakukan untuk mencegah terjadinya kredit macet yang bisa mengganggu jalannya usaha koperasi dan juga merugikan kinerja keuangan koperasi terutama dalam pencapaian keuntungan.

Claro hotel makassar memiliki koperasi karyawan yang didirikan pada tahun 2007. Anggota KOPKAR Claro hotel Makassar terdiri dari semua karyawan mulai dari staf biasa sampai pemegang jabatan head manajer claro hotel Makassar. Oleh karena itu koperasi karyawan claro hotel digunakan sebagian banyak oleh karyawan claro hotel sebagai lembaga pengambilan kredit.

Kebijakan kredit yang dilakukan oleh koperasi karyawan claro hotel sangat penting sekali bagi para anggotanya karena dengan pemberian kredit ini dapat meningkatkan kesejahteraan bagi para anggotanya. Fasilitas kredit yang diberikan koperasi karyawan claro hotel kepada anggota selain membantu para anggota, usaha ini juga bertujuan untuk mendapatkan laba atau dalam koperasi dikenal dengan Sisa Hasil Usaha (SHU) yang diinginkan.

Bentuk pinjaman yang ditawarkan oleh koperasi karyawan claro hotel sangat beragam, berdasarkan kebutuhan pihak yang membutuhkan. Hal ini juga yang menyebabkan banyaknya kebijaksanaan yang dikeluarkan dalam pemberian kredit. Sebab apabila sedikit saja kelonggaran ataupun kesalahan yang tidak disengaja, maka akan menyebabkan masalah bagi pihak koperasi.

Melihat dari uraian di atas, maka penulis tertarik untuk melakukan penelitian yang berjudul "Pengaruh Kebijakan Kredit Terhadap Kinerja Keuangan Koperasi Karyawan Claro 
Hotel Makassar (Periode Tahun 2014 2018)"

\section{METODE PENELITIAN}

\subsection{Teknik Analisis Data}

Untuk menjawab permasalahan pertama, dilakukan perhitungan kebijakan kredit dan perhitungan kinerja keuangan. Untuk menghitung kebijakan kredit menggunakan rasio perputaran piutang (Receivables Turn Over Ratio) yaitu:

\section{Rasio Perputaran Piutang

$$
=\frac{\text { Penjualan }}{\text { Rata }- \text { Rata Piutang Dagang }}
$$

a. Untuk menghitung kinerja keuangan menggunakan rasio likuiditas dan rasio profitabilitas:

1) Rasio likuiditas menggunakan pendekatan rasio lancar dengan perhitungan adalah sebagai berikut:

Rasio Lancar $=\frac{\text { Aset Lancar }}{\text { Hutang Lancar }} \times 100 \%$

2) Rasio profitabilitas menggunakan pendekatan net profit margin dengan perhitungan adalah sebagai berikut:

Laba Bersih Setelah Pajak

$$
\text { Penjualan }
$$

Setelah melakukan perhitungan rasio, kemudian melakukan analisis time series (analisis trend) pada variabel rasio perputaran piutang, rasio likuiditas, rasio profitabilitas serta membuat grafik perkembangannya.

b. Untuk menjawab permasalahan yang kedua dilakukan uji hipotesis dengan:

1) Melakukan koefisien regresi sederhana. Model persamaan analisis regresi sederhana yang digunakan yaitu:

$$
\mathrm{Y}=\mathrm{a}+\mathrm{bX}
$$

Perhitungan koefisien regresi akan menggunakan SPSS 17.00 for windows. Menurut Sugiyono, pedoman untuk memberikan interprestasi koefisien korelasi, sebagai berikut:

$0,00-0,199=$ sangat rendah

$0,20-0,399=$ rendah

$0,40-0,599=$ sedang

$0,60-0,799=$ kuat

$0,80-1,000=$ sangat kuat

2) Koefisien Determinasi $R^{2}$

Koefisien Determinasi $\mathrm{R}^{2}$ pada dasarnya untuk mengetahui seberapa besar pengaruh variabel indenpenden terhadap variabel dependen. Nilai $\mathrm{R}^{2}$ berkisar antara 0 sampai dengan 1 , bila $\mathrm{R}^{2}=1$ berarti variabel indenpenden memiliki hubungan yang sempurna terhadap variabel dependen.

3) Uji Hipotesis (Uji t Parsial)

Uji $t$ digunakan untuk menguji pengaruh variabel bebas terhadap variabel terikat secara parsial. Pengujian dilakukan dengan menggunakan significance level $0,05 \quad(\alpha=5 \%)$. Penerimaan atau penolakan hipotesis. Apabila nilai signifikan $\mathrm{t}>0,05$ maka $\mathrm{H}_{0}$ diterima dan $\mathrm{H}_{\mathrm{a}}$ ditolak, artinya tidak terdapat pengaruh yang signifikan antara variabel indenpenden terhadap variabel dependen.

\section{HASIL DAN PEMBAHASAN}

\subsection{Perputaran Piutang}

Langkah pertama adalah menghitung rasio perputaran piutang (Receivables Turn Over Ratio) pertahunnya (2014-2018). Perputaran piutang ini sangat penting untuk menaikan likuiditas dan akan mempengaruhi kebijakan kredit yang akan diberikan pada anggotanya. Hasil 
analisis perputaran piutang periode 2014-2018 pada KopKar CHM disajikan pada tabel 4.1 dengan rumus dan hasil sebagai berikut:

\section{Rasio Perputaran Piutang}

Penjualan

$$
\begin{array}{r}
=\frac{\text { Rata }- \text { Rata Piutang Dagang }}{\text { - } 2014=\frac{368.415 .796,17}{258.704 .073,67}=1,42}
\end{array}
$$

- $2015=\frac{372 \cdot 966 \cdot 889,25}{263.255 \cdot 165,25}=1,41$

- $2016=\frac{278.621 .093,2}{45.096 .965,58}=6,18$

- $2017=\frac{385.377 .982,92}{242.118 .587}=1,59$

- $2018=\frac{396.240 .723}{252.366 .568}=1,46$

Tabel 4.1

Perputaran Piutang

\begin{tabular}{|c|c|c|c|}
\hline TAHUN & PENJUALAN (Rp) & $\begin{array}{c}\text { RATA-RATA PIUTANG } \\
\text { DAGANG (Rp) }\end{array}$ & $\begin{array}{c}\text { RASIO PERPUTARAN } \\
\text { PIUTANG (\%) }\end{array}$ \\
\hline 2014 & $368.415 .796,17$ & $258.704 .073,67$ & 1,42 \\
\hline 2015 & $372.966 .889,25$ & $263.255 .165,25$ & 1,41 \\
\hline 2016 & $278.621 .093,2$ & $45.096 .965,58$ & 6,18 \\
\hline 2017 & $385.377 .982,92$ & 242.118 .587 & 1,59 \\
\hline 2018 & 396.240 .723 & 252.366 .568 & 1,46 \\
\hline
\end{tabular}

Hasil Olahan Data Perputaran Piutang 2019

Dari tabel 4.1 menunjukkan bahwa tahun 2015 mengalami penurunan atau dalam penagihan yang kurang baik, tetapi tahun 2016 mengalami kenaikan yang cukup drastis hal ini berarti KopKar CHM telah memperbaiki kinerjanya dalam penagihan piutangnya.

\subsection{Analisis Kinerja Keuangan}

Langkah selanjutnya ialah menghitung/menganalisis kinerja keuangan dengan menggunakan rumus Rasio likuiditas dan Rasio profitabilitas dari tahun 2014-2018 seperti berikut:

\section{a. Rasio Likuiditas}

Hasil anaisis rasio lancar periode 2014-2018 di KopKar CHM disajikan dalam rumus perhitungan dan tabel 4.2 dan gambar 4.2 sebagai berikut:

$$
\text { Rasio Lancar }=\frac{\text { Aset Lancar }}{\text { Hutang Lancar }} \times 100 \%
$$

a. $2014=\frac{4.121 .888 .439}{124.836 .900} \times 100 \%=$ 3.301

b. $2015=\frac{4.176 .501 .558}{179.450 .019} \times 100 \%=$ 2.327

C. $2016=\frac{4.151 .525 .840}{17.475 .380} \times 100 \%=$ 23.756

d. $2017=\frac{4.785 .701 .055}{124.836 .900} \times 100 \%=$ 3.833

e. $2018=\frac{5.546 .712 .170}{213.316 .468} \times 100 \%=$ 2.600 
Tabel 4.2

Rasio Likuiditas

\begin{tabular}{|c|c|c|c|}
\hline TAHUN & ASET LANCAR (Rp) & HUTANG LANCAR (Rp) & RASIO LANCAR (\%) \\
\hline 2014 & 4.121 .888 .439 & 124.836 .900 & 3.301 \\
\hline 2015 & 4.176 .501 .558 & 179.450 .019 & 2.327 \\
\hline 2016 & 4.151 .525 .840 & 17.475 .380 & 23.756 \\
\hline 2017 & 4.785 .701 .055 & 124.836 .900 & 3.833 \\
\hline 2018 & 5.546 .712 .170 & 213.316 .468 & 2.600 \\
\hline
\end{tabular}

Hasil Olahan Data Rasio Likuiditas 2019

Gambar 4.2

Kondisi Likuiditas tahun 2014-2018 KopKar CHM

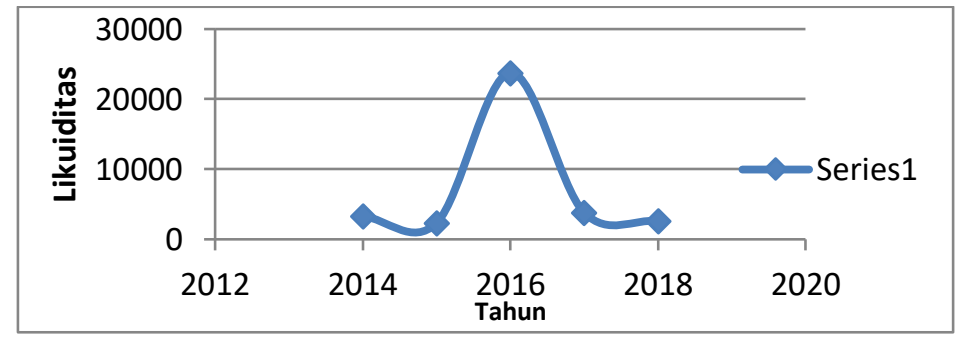

tahun 2015, rasio lancar 2016

Tahun 2016 aktiva lancar KopKar CHM turun dari Rp. 4.176.501.558,menjadi Rp. 4.151.525.840,- penurunan ini utamanya disebabkan oleh "bank" sebesar Rp. 424.797.400,- dengan total penurunan sebesar $18 \%$ sedangkan hutang lancar juga mengalami penurunan dari Rp. 179.450.019,menjadi Rp. 17.475.380,- penurunan ini utamanya disebabkan hutang toko, hutang belanja wajib sebesar $\mathrm{Rp}$. 17.475.380,- dengan total penurunan $572 \%$.

Kondisi rasio lancar KopKar CHM tahun 2016 sebesar 23.756\%, hal ini menunjukkan bahwa kondisi KopKar CHM pada tahun 2016 dalam kondisi likuid. Pada tahun 2016, setiap Rp. 1,hutang jangka pendek dijamin dengan 5,57 aktiva lancar yang dimiliki KopKar CHM. Apabila dibandingkan dengan mengalami kenaikan sebesar 1.020,88\%.

Tahun 2017 aktiva lancar KopKar CHM naik dari Rp. 4.151.525.840,menjadi Rp. 4.785.701.055,- kenaikan ini utamanya disebabkan oleh "bank" sebesar Rp. 1.396.574.567,- dengan kenaikan total sebesar $716 \%$ sedangkan hutang lancar juga mengalami kenaikan dari Rp. 17.475.380,- menjadi Rp. 124.836.900,- kenaikan ini utamanya disebabkan hutang toko, hutang belanja wajib sebesar Rp. 145.951.602,- dengan total penurunan $477 \%$.

Kondisi rasio lancar KopKar CHM tahun 2017 sebesar 3.833\%, hal ini menunjukkan bahwa kondisi KopKar CHM pada tahun 2017 dalam kondisi likuid. Pada tahun 2017, setiap Rp. 1,hutang jangka pendek dijamin dengan 0.29 aktiva lancar yang dimiliki KopKar CHM. Apabila dibandingkan dengan 
tahun 2016, rasio lancar 2017 mengalami penurunan sebesar $61.977,56 \%$. Faktor utama yang menyebabkan terjadinya penurunan ini karena ada kenaikan hutang toko/cafe sebesar Rp. 923.873.512,-

Tahun 2018 aktiva lancar KopKar CHM naik dari Rp. 4.785.701.055,menjadi Rp. 5.546.712.170,- kenaikan ini utamanya disebabkan oleh "bank" sebesar Rp. 761.011.115,- dengan kenaikan total sebesar 180\% sedangkan hutang lancar juga mengalami kenaikan dari Rp. 124.836.900,- menjadi Rp. 213.316.468,- kenaikan ini utamanya disebabkan hutang toko, hutang belanja wajib sebesar Rp. 88.479.568,- dengan kenaikan total sebesar $468 \%$.

Kondisi rasio lancar KopKar CHM tahun 2018 sebesar 2.600\%, hal ini menunjukkan bahwa kondisi KopKar CHM pada tahun 2018 dalam kondisi likuid. Pada tahun 2018, setiap Rp. 1,hutang jangka pendek dijamin dengan 0,33 aktiva lancar yang dimiliki KopKar CHM. Apabila dibandingkan dengan tahun 2017, rasio lancar 2018 mengalami penurunan sebesar $147,42 \%$. Faktor utama yang menyebabkan terjadinya penurunan ini karena ada kenaikan hutang toko/cafe sebesar Rp. 3.667.111.171,--

Berdasarkan hasil perhitungan
KopKar CHM sampai tahun 2018 masih dalam kondisi likuid, hal ini ditunjukkan oleh rasio lancar $>100 \%$ atau dengan kata lain KopKar CHM masih mampu memenuhi kewajiban keuangannya yang harus dipenuhi atau saat ditagih. Apabila diamati data rasio likuiditas selama 5 tahun terakhir (Gambar 4.1) menunjukkan bahwa KopKar CHM mengalami penurunan likuiditas. Dengan melihat perkembangan likuiditas selama 5 tahun terakhir tersebut menunjukkan bahwa kinerja keuangan KopKar CHM mengalami penurunan, sehingga menjadi peringatan bagi pengurus untuk meningkatkan kinerjanya.

\section{b. Rasio Profitabilitas}

Hasil analisis net profit margin periode 2014-2018 di KopKar CHM disajikan pada tabel 4.3 dan gambar 4.3 dengan rumus dan hasil perhitungan sebagai berikut:

Laba Bersih Setelah Pajak

$$
\text { Penjualan }
$$
a. $\quad 2014=\frac{398.302 .426,83}{368.415 .796}=1,081$
b. $\quad 2015=\frac{370.669 .753,12}{372.966 \cdot 889,25}=0,99$
c. $2016=\frac{375.814 .244}{278.621 .093,2}=1,348$
d. $\quad 2017=\frac{451.606 .405,64}{385.377 .982,92}=1,171$
e. $\quad 2018=\frac{528.462 .626,51}{396.240 .723}=1,333$

Tabel 4.3 rasio likuiditas menunjukkan bahwa

Perkembangan net profit margin

\begin{tabular}{|c|c|c|c|}
\hline TAHUN & $\begin{array}{c}\text { LABA BERSIH SETELAH } \\
\text { PAJAK (Rp) }\end{array}$ & $\begin{array}{c}\text { PENJUALAN } \\
(\mathrm{Rp})\end{array}$ & $\begin{array}{c}\text { PROFITABILITAS } \\
(\%)\end{array}$ \\
\hline 2014 & $398.302 .426,83$ & $368.415 .796,17$ & 1.081 \\
\hline 2015 & $370.669 .753,12$ & $372.966 .889,25$ & 99 \\
\hline 2016 & 375.814 .244 & $278.621 .093,2$ & 1.348 \\
\hline 2017 & $451.606 .405,64$ & $385.377 .982,92$ & 1.171 \\
\hline 2018 & $528.462 .626,51$ & 396.240 .723 & 1.333 \\
\hline
\end{tabular}

Hasil Olahan Data Rasio Profitabilitas 2019 


\section{Gambar 4.3}

\section{Kondisi Profitabilitas tahun 2014-2018 KopKar CHM}

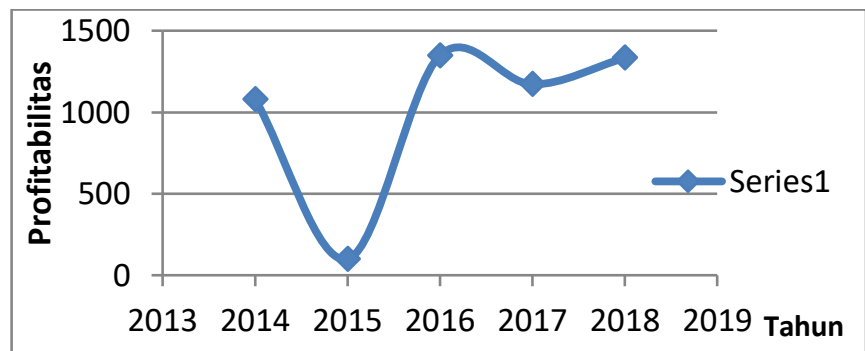

Tahun 2016 laba bersih KopKar CHM naik dari Rp. 370.669.753,12menjadi Rp. 375.814.244,- dengan kenaikan mencapai 98,63\%. Sedangkan hasil penjualan turun dari Rp. 372.966.889,25- menjadi Rp. 278.621.093,2- penurunan ini utamanya disebabkan oleh persediaan awal toko, persediaan awal cafe pembelian toko, pembelian cafe, persediaan akhir toko, persediaan akhir cafe yang naik dari Rp. 3.101.500.333,- menjadi Rp. 4.386.630.890,- dengan kenaikan total sebesar 70,7\%. Profitabilitas KopKar CHM tahun 2016 mengalami kenaikan sebesar $1.249 \%$.

Tahun 2017 laba bersih KopKar CHM mengalami kenaikan dari Rp. 375.814.244,- menjadi Rp. 451.606.405,64- mencapai 83,21\% . sedangkan hasil penjualan mengalami kenaikan dari Rp. 278.621.093,2menjadi Rp. 385.377.982,92-. Kenaikan ini utamanya disebabkan oleh hasil bunga pengkreditan sebesar Rp. 4.624.535.795,- dengan kenaikan total sebesar 72,29\%. Profitabilitas KopKar CHM tahun 2017 mengalami penurunan sebesar $177 \%$.

Tahun 2018 laba bersih KopKar CHM mengalami kenaikan dari Rp. 451.606.405,64- menjadi Rp. 528.462.626,51- mencapai 85,45\%. Sedangkan hasil penjualan mengalami kenaikan dari Rp. 385.377.982,92menjadi Rp. 396.240.723,- mencapai $90,44 \%$. Kenaikan ini utamanya disebabkan oleh hasil bunga pengkreditan sebesar Rp. 4.754.888.676,- dengan kenaikan total sebesar $97,25 \%$.

Profitabilitas KopKar CHM tahun 2018 sebesar $1.333 \%$ apabila dibandingkan dengan tahun 2017, profitabilitas mengalami kenaikan sebanyak $162 \%$. Faktor utama terjadinya kenaikan profitabilitas dikarenakan adanya peningkatan pendapatan toko dan cafe.

Dengan mencermati data di atas menunjukkan bahwa profitabilitas KopKar CHM mengalami fluktuasi atau menggambarkan ketidaktetapan naik dan turunnya profitabilitas dari tahun 2014-2018. Penurunan tertinggi terjadi pada tahun 2014-2015 sebanyak 982\%. Kemudian pada tahun 2016 mengalami peningkatan drastis sebanyak $1.249 \%$ lalu pada tahun 2017 kembali mengalami penurunan profitabilitas sebanyak $177 \%$ dan kembali mengalami kenaikan profitabilitas di tahun 2018 sebanyak $162 \%$.

Dengan melihat perkembangan selama 5 tahun terakhir menunjukkan bahwa kinerja keuangan KopKar CHM mengalami ketidak stabilan profitabilitas dilihat dari naik turunnya hasil grafik, 
sehingga menjadi peringatan bagi pengurus untuk meningkatkan kinerjanya.

\section{c. Kebijakan Kredit}

Kebijakan kredit (simpan pinjam) kepada anggota KopKar CHM ditentukan oleh besarnya dana yang dialokasikan untuk simpan pinjam. Sejak tahun 2007

KopKar CHM telah membentuk unit simpan pinjam (USP). Urusan yang terkait dengan utang piutang anggota KopKar CHM dilayani oleh USP. Presentase kebijakan kredit yang dialokasikan ke anggota KopKar CHM tahun 2014-2018 disajikan pada tabel 4.4

Tabel 4.4

Data Presentase Kebijakan Kredit KopKar CHM

\begin{tabular}{|l|l|l|l|l|l|}
\hline \multirow{2}{*}{ URAIAN } & \multicolumn{5}{|c|}{ TAHUN } \\
\cline { 2 - 6 } & \multicolumn{1}{|c|}{2014} & \multicolumn{1}{|c|}{2015} & \multicolumn{1}{|c|}{2016} & \multicolumn{1}{c|}{2017} & \multicolumn{1}{c|}{2018} \\
\hline BARANG & $507.784,75$ & $722.118,16$ & $5.806 .782 .035,6$ & $864.495,25$ & $846.935,58$ \\
\hline REGULER & 3.783 .865 & $7.544 .166,58$ & $1.287 .501 .466,13$ & $10.251 .765,83$ & $6.540 .773,833$ \\
\hline EXTRA CASH & 5.032 .123 & 6.212 .500 & $12.009 .900,75$ & $8.692 .867,08$ & $8.259 .932,58$ \\
\hline JUMLAH & 9.323 .772 & 14.471 .444 & 7.097 .293 .401 & 19.809 .127 & 15.665 .640 \\
\hline $\begin{array}{l}\text { PRESENTASE } \\
\text { (\%) }\end{array}$ & & $155 \%$ & $490,4 \%$ & $0,027 \%$ & $79,0 \%$ \\
\hline
\end{tabular}

Hasil Olahan Data Presentase Data Kredit 2019

Dari tabel 4.4 terlihat bahwa kebijakan kredit yang dialokasikan selama 5 tahun terakhir (2014-2018) berfluktuatif. Tahun 2016 kebijakan kredit yang dialokasikan untuk tertinggi, yaitu Rp. 7.097.293.401,- dengan presentase sebesar 490,4\%. Pemberian kredit pada anggota berpengaruh pada likuiditas dan profitabilitas KopKar CHM.

\subsection{Analisis Regresi Linear Sederhana}

Analisis regresi linear sederhana digunakan untuk menguji hipotesis tentang pengaruh kebijakan kredit terhadap kinerja keuangan yang diperoleh dengan menggunakan program SPSS (Statistical Product and Service Solution) versi 17.0 dapat dilihat pada tabel 4.5 berikut ini.

Tabel 4.5

Analisis Regresi Linear Sederhana

Coefficients ${ }^{a}$

\begin{tabular}{|c|c|c|c|c|c|c|c|c|c|c|}
\hline \multirow[b]{2}{*}{ Model } & \multicolumn{2}{|c|}{$\begin{array}{l}\text { Unstandardized } \\
\text { Coefficients }\end{array}$} & $\begin{array}{l}\text { Standardized } \\
\text { Coefficients }\end{array}$ & \multirow[b]{2}{*}{$\mathrm{t}$} & \multirow[b]{2}{*}{ Sig. } & \multicolumn{3}{|c|}{ Correlations } & \multicolumn{2}{|c|}{$\begin{array}{l}\text { Collinearit } \\
\text { y Statistics }\end{array}$} \\
\hline & B & Std. Error & Beta & & & $\begin{array}{l}\text { Zero- } \\
\text { order }\end{array}$ & Partial & $\begin{array}{c}\text { Par } \\
\mathrm{t}\end{array}$ & $\begin{array}{c}\text { Toleran } \\
\text { ce }\end{array}$ & $\begin{array}{l}\text { VI } \\
\mathrm{F}\end{array}$ \\
\hline $1 \begin{array}{cc}1 & \text { (Cons } \\
& \tan t)\end{array}$ & $\begin{array}{r}4062 . \\
559\end{array}$ & 4349.780 & & .934 & .354 & & & & & \\
\hline $\begin{array}{l}\text { Kebij } \\
\text { akan_- } \\
\text { Kredi } \\
\text { t }\end{array}$ & .003 & .005 & .080 & .614 & .542 & .080 & .080 & $\begin{array}{r}.08 \\
0\end{array}$ & 1.000 & $\begin{array}{r}1 . \\
0 \\
0 \\
0\end{array}$ \\
\hline
\end{tabular}

a. Dependent Variable: Kinerja_Keuangan

Sumber : Hasil olahan menggunakan spss versi 17.0 
Berdasarkan tabel 4.5 di atas, maka dapat dibuat persamaan regresi sederhana dimana nilai a yang diperoleh sebesar 4062,559, nilai b sebesar 0,003, sehingga apabila dirumuskan dalam persamaan regresi sederhana maka hasilnya sebagai berikut:

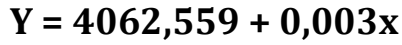

Dari persamaan regresi tersebut, hasil regresi dapat dijelaskan sebagai berikut:

a. Nilai konstanta sebesar 4062,559 yang berarti bahwa apabila nilai koefisien variabel indenpenden sama dengan nol, maka kinerja keuangan sebesar 4062,559.

b. Koefisien regresi variabel kinerja keuangan sebesar 0,003 ini menunjukkan bahwa setiap kenaikan 1\% maka akan menaikkan kinerja keuangan sebesar 0,003.

\subsection{Koefisien Determinasi $\mathrm{R}^{2}$}

Koefisien determinasi ( $\mathrm{R}$ square) menunjukkan seberapa besar variabel indenpenden menjelaskan variabel dependennya. Apabila nilai $\mathrm{R}$ square makin mendekati satu, maka variabelvariabel indenpendennya telah memberikan variasi variabel dependen. Berdasarkan hasil pengolahan data dengan menggunakan SPSS versi 17.0 maka dapat diperoleh hasil sebagai berikut

Tabel 4.6

\section{Koefisien Determinasi $\mathbf{R}^{2}$}

Model Summaryb

\begin{tabular}{|c|c|c|c|c|c|c|c|c|c|c|}
\hline \multirow[b]{2}{*}{ Mode } & \multirow[b]{2}{*}{$\mathrm{R}$} & \multirow[b]{2}{*}{$\begin{array}{c}\mathrm{R} \\
\text { Square }\end{array}$} & \multirow[b]{2}{*}{$\begin{array}{c}\text { Adjuste } \\
\text { d R } \\
\text { Square }\end{array}$} & \multirow{2}{*}{$\begin{array}{c}\text { Std. } \\
\text { Error of } \\
\text { the } \\
\text { Estimate }\end{array}$} & \multicolumn{5}{|c|}{ Change Statistics } & \multirow[b]{2}{*}{ Durbin-Watson } \\
\hline & & & & & $\begin{array}{c}\mathrm{R} \\
\text { Square } \\
\text { Change }\end{array}$ & $\begin{array}{c}\text { F } \\
\text { Chang } \\
\text { e }\end{array}$ & df1 & df2 & $\begin{array}{l}\text { Sig. F } \\
\text { Change }\end{array}$ & \\
\hline 1 & $.080^{\mathrm{a}}$ & .006 & -.011 & $\begin{array}{r}8252.60 \\
535\end{array}$ & .006 & .377 & 1 & 58 & .542 & 2.376 \\
\hline
\end{tabular}

a. Predictors: (Constant), Kebijakan_Kredit

b. Dependent Variable: Kinerja_Keuangan

Sumber: Hasil olahan menggunakan spss versi 17.0

Berdasarkan tabel $4.6 \mathrm{di}$ atas, diperoleh perhitungan dengan menggunakan program SPSS versi 17.0 tersebut, koefisien determinasi ( $\mathrm{R}$ square) sebesar 0,006 yang berarti setiap perubahan kebijakan kredit yang dapat dijelaskan variabel dependen (kinerja keuangan) adalah sebesar 0,06\% dan sisanya 99,4\% dijelaskan oleh faktor-faktor lain yang tidak dijelaskan dalam penelitian ini.

\subsection{Uji Hipotesis (Uji t parsial)}

Uji $t$ digunakan untuk menguji pengaruh variabel bebas terhadap variabel terikat secara parsial. Pengujian dilakukan dengan menggunakan significance level $0,05 \quad(\alpha=5 \%)$. Penerimaan atau penolakan hipotesis dilakukan seebagai berikut:

a. Apabila nilai signifikan $\mathrm{t}>0,05$ maka $\mathrm{H}_{0}$ diterima dan $\mathrm{H}_{\mathrm{a}}$ ditolak, artinya tidak terdapat pengaruh yang 


$\begin{array}{llll}\text { signifikan } & \text { antara } & \text { variabel } & \text { terdapat pengaruh yang signifikan } \\ \begin{array}{l}\text { indenpenden } \\ \text { dependen. }\end{array} & \text { terhadap } & \text { variabel } & \begin{array}{l}\text { antara variabel indenpenden } \\ \text { terhadap variabel dependen. }\end{array}\end{array}$

b. Apabila nilai signifikan $\mathrm{t}<0,05$ maka

$\mathrm{H}_{0}$ ditolak dan $\mathrm{H}_{\mathrm{a}}$ diterima, artinya

Tabel 4.7

\section{Uji t Parsial}

\section{Coefficients $^{\mathrm{a}}$}

\begin{tabular}{|c|c|c|c|c|c|c|c|c|c|c|}
\hline \multirow[b]{2}{*}{ Model } & \multicolumn{2}{|c|}{$\begin{array}{l}\text { Unstandardized } \\
\text { Coefficients }\end{array}$} & \multirow{2}{*}{ 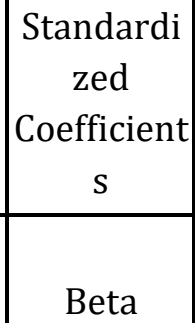 } & \multirow[b]{2}{*}{$\mathrm{t}$} & \multirow[b]{2}{*}{ Sig. } & \multicolumn{3}{|c|}{ Correlations } & \multicolumn{2}{|c|}{$\begin{array}{l}\text { Collinearity } \\
\text { Statistics }\end{array}$} \\
\hline & B & $\begin{array}{l}\text { Std. } \\
\text { Error }\end{array}$ & & & & $\begin{array}{l}\text { Zero- } \\
\text { order }\end{array}$ & $\begin{array}{c}\text { Partia } \\
1\end{array}$ & $\begin{array}{c}\text { Par } \\
\mathrm{t}\end{array}$ & $\begin{array}{c}\text { Toleran } \\
\text { ce }\end{array}$ & VIF \\
\hline 1 (Constant) & $\begin{array}{r}4062.5 \\
59\end{array}$ & $\begin{array}{r}4349.7 \\
80\end{array}$ & & .934 & .354 & & & & & \\
\hline $\begin{array}{l}\text { Kebijakan_Kr } \\
\text { edit }\end{array}$ & .003 & .005 & .080 & .614 & .542 & .080 & .080 & $\begin{array}{r}.08 \\
0\end{array}$ & 1.000 & $\begin{array}{r}1.00 \\
0\end{array}$ \\
\hline
\end{tabular}

a. Dependent Variable: Kinerja_Keuangan

Sumber : Hasil olahan menggunakan spss versi 17.0

Pada tabel 4.7, dapat dijelaskan hasil pengujian hipotesis t parsial bahwa, variabel kinerja keuangan memiliki nilai t sebesar 0,614 dengan nilai signifikan 0,542 yang lebih besar dari 0,05 maka $\mathrm{H}_{0}$ diterima dan $\mathrm{H}_{\mathrm{a}}$ ditolak. Dengan demikian, variabel kinerja keuangan secara parsia berpengaruh positif dan tidak signifikan terhadap kinerja keuangan.

\subsection{Pembahasan}

Pembahasan dalam penelitian ini menguraikan pengaruh variabel indenpenden (Kebijakan Kredit) terhadap variabel dependen (Kinerja Keuangan) pada koperasi karyawan claro hotel makassar (periode tahun 2014-2018). Tingkat likuiditas koperasi karyawan claro hotel makassar selama tahun 2014-2018 mengalami penurunan sebanyak 126,96\% yang menandakan keadaan likuiditas koperasi kurang baik. Meski begitu likuiditas koperasi karyawan claro hotel makassar tahun 2016 juga sempat mengalami peningkatan yang sangat drastis sebanyak 1.020,88\%.

Tingkat profitabilitas koperasi karyawan claro hotel makassar berdasarkan hasil penelitian menunjukkan kinerja keuangan yang baik karena laba bersih dari setiap penjualan yang diperoleh koperasi dari tahun ketahun menunjukkan peningkatan.

Berdasarkan penelitian yang dilakukan, hasil yang didapatkan berpengaruh positif, hal tersebut dapat diartikan bahwa arah variabel dependen dan variabel dependen searah, apabila kebijakan kredit meningkat maka kinerja keuangan juga meningkat, begitupun 
sebaliknya. Tidak signifikan yang diperoleh menandakan bahwa kebijakan kredit yang besar tidak selalu diikuti dengan peningkatan kinerja keuangan, hal ini juga berarti bahwa kebijakan kredit tidak memberi konstribusi laba/SHU yang baik terhadap kinerja keuangan KopKar CHM. Hal ini disebabkan karena kebijakan kredit koperasi bersifat lunak yaitu kredit yang diberikan koperasi kepada anggotanya mempunyai bunga rendah dan waktu pengembaliannya tidak mengikat atau longgar sehingga hal ini juga menandakan bahwa kebijakan kredit bukan merupakan salah satu variabel yang dijadikan acuan oleh pengurus koperasi dalam menciptakan laba/SHU koperasi untuk kinerja keuangan koperasi, karena masih terdapat faktor lain diluar kebijakan kredit yang dimiliki koperasi seperti pendapatan dari toko dan cafe yang tidak diteliti dalam penelitian ini.

Adapun hasil penelitian ini sejalan dengan penelitian yang dilakukan $\mathrm{Ni}$ Wayan Ana Purnamayanti, I Wayan Suwendra, Ni Nyoman Yulianthini (2014) menyatakan bahwa pemberian kredit berpengaruh positif tidak signifikan terhadap pendapatan UMKM.

\section{PENUTUP}

\subsection{Simpulan}

Berdasarkan hasil penelitian dan pembahasan yang telah dilakukan, maka diperoleh kesimpulan sebagai berikut:

1. Rasio perputaran kredit KopKar CHM mengalami fluktuasi atau ketidak tetapan hasil presentase perputaran kredit yang tiap tahunnya kadang mengalami penurunan dan kadang mengalami peningkatan.

2. Kebijakan kredit secara parsial berpengaruh positif dan tidak signifikan terhadap kinerja keuangan koperasi karyawan claro hotel makassar.

3. Kebijakan kredit tidak memberi konstribusi laba/SHU yang banyak atau tidak begitu mempengaruhi hasil kinerja keuangan KopKar CHM

\subsection{Saran}

Berdasarkan kesimpulan yang diperoleh dalam penelitian ini, maka dapat diberikan saran sebagai berikut:

1. KOPKAR CHM dapat terus mempertahankan Kebijakan Kredit yang diberikan kepada anggotanya karena dapat sangat membantu dan mempermudah bagi para anggota dalam memenuhi kebutuhannya.

2. Bagi peneliti yang tertari meneliti dengan judul yang sama diharapkan dapat menambah periode pengamatan dan menggunakan variabel lain selain likuiditas, dan profitabilitas.

\section{DAFTAR PUSTAKA}

Darmawan, Arif. 2017. "Faktor-Faktor Yang Mempengaruhi Kebijakan Penyaluran Kredit Perbankan Pada Bank Umum Di Indonesia Tahun 2010-2015. Tesis tidak diterbitkan. Yogyakarta: Universitas Negeri Yogyakarta.

Dewa, A.P. dan Sitohang. 2015. "Analisis Kinerja Keuangan PT. Indofood Sukses Makmur, Tbk di Bursa Efek Indonesia". Tesis tidak diterbitkan. Surakarta: Universitas Muhammadiyah Surakarta.

Fahmi, Irham. 2014. "Analisis Kinerja Keuangan". Cetakan 3. Bandung. Alfabeta.

. 2014. "Manajemen Keuangan Perusahaan dan Pasar Modal". Jakarta Selatan. 
Hery. 2015. "Analisis Laporan Keuangan”. Edisi 1. Yogyakarta: Center For. Academic.

Jopie Jusuf. 2014. “Analisis Kredit Untuk Account Officer. Jakarta: PT. Gramedia.

Kasmir. 2013. "Bank dan Lembaga Keuangan Lainnya". Jakarta: Rajawali pers.

2014. "Analisis Laporan Keuangan". Edisi Pertama, Cetakan Ketujuh. Jakarta: PT. Rajagrafindo Persada.

Kurniawan Chanda, Desva Arianti Vera. 2018. "Analisis Kinerja Keuangan Pada Koperasi Simpan Pinjam Wira Karya lahat Kabupaten Lahat". Jurnal Nerc. Vol 2 No 1.

Muhardi, Werner R. 2013. "Analisis Laporan Keuangan, Proyeksi dan Valuasi Saham. Jakarta: Salemba Empat

Munawir. 2014. "Analisis Laporan Keuangan”. Yogyakarta: Liberty.

Nisa, Chaerani. 2016. "Analisis Dampak Kebijakan Penyaluran Kredit Kepada UMKM Terhadap Pertumbuhan Pembiayaan UMKM Oleh perbankan". Derema Jurnal Manajemen. Vol 11 No 2.

Ni Wayan Ana Purnamayanti, I Wayan Suwendra, Ni Nyoman Yulianthini. 2014. "Pengaruh Pemberian Kredit Dan Modal Terhadap Pendapatan UMKM". e-Jurnal Bisma Universitas Pendidikan Gunesha Jurusan Manajemen. Vol 2.

Rudianto. 2013. “Akuntansi Manajemen Informasi Untuk Pengambilan Keputusan". Jakarta: Erlangga.

Sugiyono. 2016. "Metode Penelitian Manajemen". Bandung: Alfabeta.

Suhendro, Dedi. 2018. "Analisis Penilaian Kinerja Keuangan Perusahaan Menggunakan Rasio Keuangan
Pada PT. Unilever Indonesia Tbk Yang Terdaftar Di Bursa Efek Indonesia (BEI)". At-Tawassuth Jurnal. Vol III No 1. 